\title{
THE POSSIBILITIES OF THE RETAINED AUSTENITE REDUCTION ON TOOL STEELS
}

\author{
László TÓTH ${ }^{1, *}$ \\ ${ }^{1}$ Óbuda University, Bánki Donát Faculty of Mechanical and Safety Engineering, \\ Material Science Department, 1081, Hungary, Budapest, Népszínház u., 8
}

\begin{abstract}
The retained austenite induces a great deal of internal stress in the steel, often manifesting itself as cracks. Retained austenite also have a negative effect on dimensional stability of the steel components. In tool steels retained austenite is considered to be highly detrimental and is the cause of many application failures. Tool steels must be able to attain high hardness, high compressive strength, good toughness to be suitable for forming of advanced high-strength steels. The high alloying elements content tool steels result is low martensite start and martensite finish temperatures. As a result, the transformation of austenite to martensite does not go to completion when quenching to room temperature. In this work the effects of tempering and cryogenic treatment were investigated for reducing the amount of residual austenite in case of a cold work tool steel and a hot work tool steel. The results showed that in the case of tool steels, during high hardening and three times tempering at high temperatures, the amount of residual austenite was significantly reduced and as a result of cryogenic treatment completely disappeared.
\end{abstract}

Keywords: tool steel, retained austenite, hardness, microstructure, cryogenic treatment.

\section{Introduction}

Austenite is an interstitial solid solution face-centered cubic phase of iron with alloying elements which formed after the allotropic transformation from ferrite (body-centered cubic phase), during the steel heating. This step is a part of a heat treatment process of the steels called austenitization. After the formation of homogenous austenite follows the quenching. The result of quenching is a martensitic structure. The martensitic transformation is diffusion less what is accompanied by lattice expansion which produce a compressive residual stress at the material surface and increases fatigue strength. Austenite that does not transform to martensite upon quenching step is called retained austenite (RA).

Retained austenite is formed when steel is not quenched to the Mf (martensite finish) temperature. In tool steels Mf temperature is below room temperature, therefore after quenching of this steel to room temperature in addition to martensite there are present a significant quantity of retained austenite. The amount of retained austenite is a function of the carbon content, alloy content, quenchant temperature, austenite grain size, cooling rate during the quenching and subsequent thermal treatments (Fig. 1). 


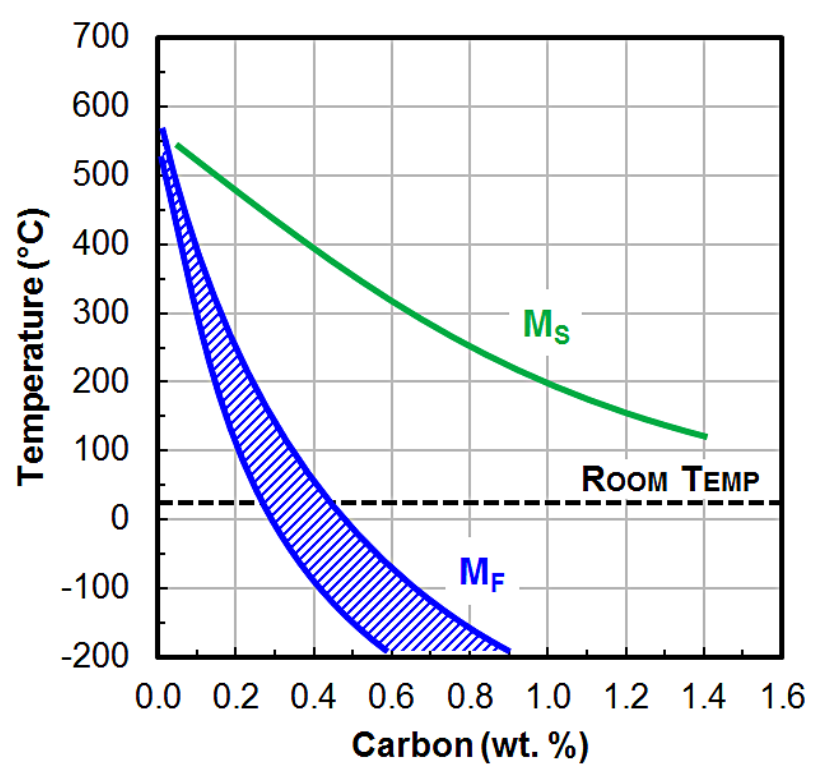

Fig. 1. Ms and Mf temperatures as a function of carbon content [1]

Depending on the chemical composition of the steel and the heat treatment technology, the retained austenite level can vary from over $50 \%$ of the structure to nearly zero. Large amounts of retained austenite (more than 15\%) can be detected and estimated by optical microscopy [2]. To measure lower amount of retained austenite are required x-ray diffraction methods [3].

The retained austenite has a detrimental effect on the properties of steel [4,5]. During heat treatments of steel, the retained austenite has a negative effect on dimensional stability. Retained austenite increase de volume of the microstructure resulting dimensional changing in the geometry of the component. Dimensional change leads to internal stresses which cause micro cracks and fatigue cracks reducing tool or component life.

Another property affected by retained austenite is hardness and abrasion resistance $[6,7,8]$. Fig. 2 shows the hardness of martensite as a function of carbon content. It is well known, that the reduction of hardness at more than 85 carbon content is due to the presence of retained austenite [9].

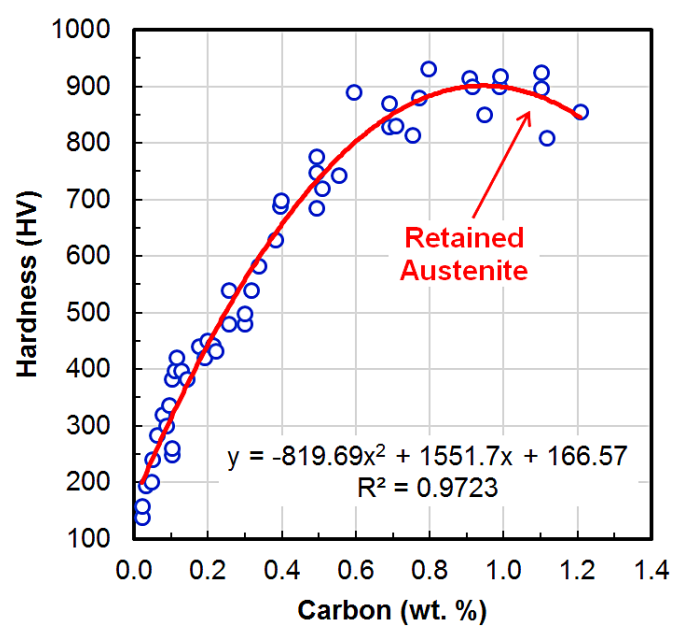

Fig. 2. The hardness of martensite as a function of carbon content 
To reduce or eliminate the retained austenite there are two ways:

- $\quad$ the quenching should be followed three times tempering [10].

- $\quad$ using cryogenic treatments [11].

Tempering the steel relieves the internal stress developed during quenching, improves the toughness by precipitation of fine carbides in the structure and reduces the carbon content from both martensite and retained austenite. Tempering process enables the steel to lower its retained austenite partially, but not completely. The only way to reduce the retained austenite quantity is the cryogenic treatment.

Cryogenic treatment is an add-on process to the conventional heat treatment processes to im-proves the mechanical properties like hardness, wear resistance, toughness and resistance to fatigue cracking [12]. In cryogenic treatment the samples after quenching are cooled from room temperature to minus degree Celsius and soaked at those temperatures for several hours. This is followed by heating to the tempering temperature.

Three times tempering provides the best properties of tool steels [13,14]. At the first tempering the retained austenite is destabilized [15-16]. Second tempering is performed to obtain the desired hardness based on the steel grade tempering diagram and it is possibly further transformation of retained austenite to martensite. Third tempering is to stabilize the structure of transformations products from second tempering and to obtain a homogenously fine, uniformly distributed precipitation of carbides.

\section{Materials and Methods}

A cold work tool steel specimen grade D2 conform AISI standard and a hot work tool steel specimen grade H11 conform AISI standard with chemical composition presented in Table 1 and Table 2, were heat treated in a cool plus sub-zero cryogenic treatment vacuum furnace (Fig. 3).

The heat treatment process was controlled by the thermocouple fixed in the center of the specimen, based on the planned heat treatment cycles (Fig. 4).

Table 1. Chemical composition of the D2 cold work tool steel

\begin{tabular}{cccccccccc}
\hline Elem. & $\mathbf{C}$ & $\mathbf{S i}$ & $\mathbf{M n}$ & $\mathbf{P}$ & $\mathbf{S}$ & $\mathbf{C r}$ & $\mathbf{M o}$ & $\mathbf{V}$ & $\mathbf{F e}$ \\
\hline$\%$, wt. & 1.56 & 0.30 & 0.31 & 0.01 & 0.01 & 11.32 & 0.78 & 0.82 & balance \\
\hline
\end{tabular}

Table 2. Chemical composition of the H11 cold work tool steel

\begin{tabular}{cccccccccc}
\hline Elem. & $\mathbf{C}$ & $\mathbf{S i}$ & $\mathbf{M n}$ & $\mathbf{P}$ & $\mathbf{S}$ & $\mathbf{C r}$ & $\mathbf{M o}$ & $\mathbf{V}$ & $\mathbf{F e}$ \\
\hline$\%$, wt. & 1.56 & 0.30 & 0.31 & 0.01 & 0.01 & 11.32 & 0.78 & 0.82 & balance \\
\hline
\end{tabular}

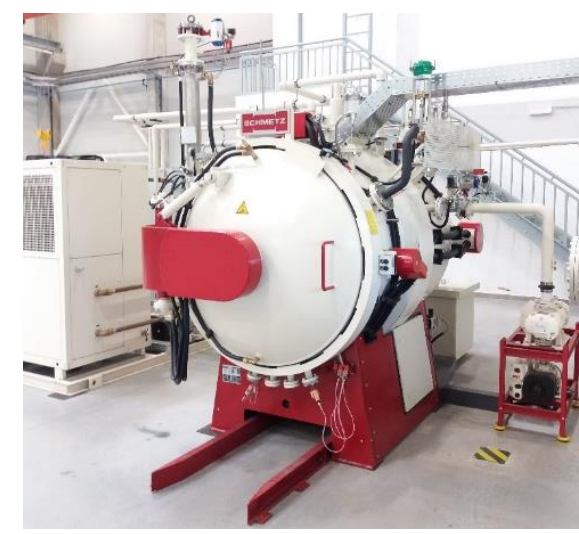

Fig. 3. Vacuum furnace

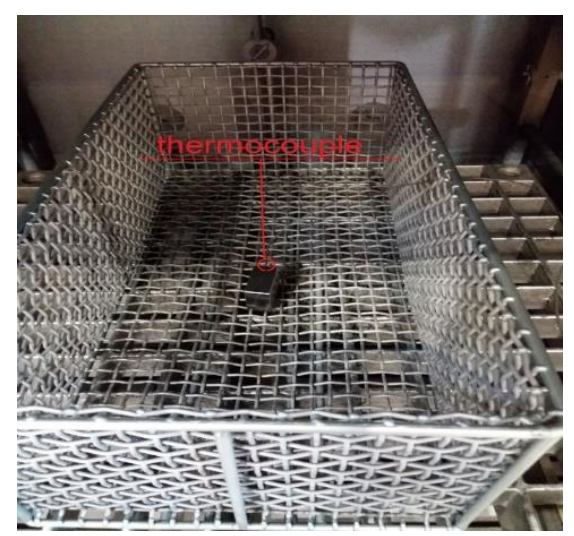

Fig. 4. The specimen and thermocouple in the furnace chamber 
The heat treatment diagrams for the specimens steel grades D2 respectively H11 are illustrated in Fig. 5.
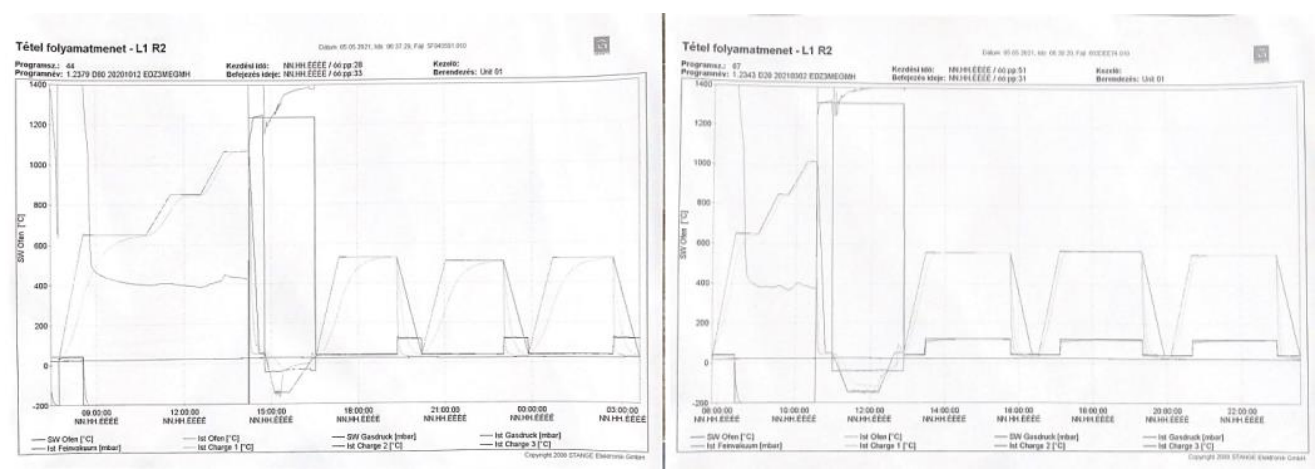

Fig. 5. The heat treatment diagram of the steel grades D2, respectively H11

\section{Results and Discussions}

The heat treatment parameters are presented in Table 3. The specimens were preheated to $650{ }^{\circ} \mathrm{C}$ and held there as long as the temperature between the core and the surface was equalized. Then these samples were heated to austenitization temperatures $\left(1070{ }^{\circ} \mathrm{C}\right.$ and $1020{ }^{\circ} \mathrm{C}$, respectively) and kept it for 10 minutes. The quenching was effectuated in nitrogen gas with 9.5 bars till $50{ }^{\circ} \mathrm{C}$. This operation was followed by cryogenic treatment with liquid nitrogen vaporized and injected in the heating zone till $-145^{\circ} \mathrm{C}$ during 120 minutes. The tempering for each grade was three times.

Table 3. The heat treatment diagram of the steel grades D2, respectively H11

\begin{tabular}{ccccc}
\hline $\begin{array}{c}\text { Specimen } \\
\text { grade }\end{array}$ & Austenitization & Quenching & $\begin{array}{c}\text { Cryogenic } \\
\text { treatment }\end{array}$ & Tempering \\
\hline $\mathrm{D} 2$ & $1070{ }^{\circ} \mathrm{C}$ & $50^{\circ} \mathrm{C}$ & $-145^{\circ} \mathrm{C}$ & $520 / 530 / 510$ \\
$\mathrm{H} 11$ & $1020^{\circ} \mathrm{C}$ & $50^{\circ} \mathrm{C}$ & $-145^{\circ} \mathrm{C}$ & $560 / 570 / 550$ \\
\hline
\end{tabular}

After the heat treatment was measured the hardness. The results are presented in Table 4.

Table 4. The measured hardness

\begin{tabular}{ccc}
\hline Specimen grade & Before heat treatment & After heat treatment \\
\hline D2 & $232 \mathrm{HB}$ & $61 \mathrm{HRC}$ \\
$\mathrm{H} 11$ & $203 \mathrm{HB}$ & $51 \mathrm{HRC}$ \\
\hline
\end{tabular}

The microstructures of the D2 sample are shown in Fig. 6.

The micrographs on Fig. 6 represent the structure of grade D2 with 1000x magnification in annealed (before heat treatment) condition (Fig. 6. a), and after heat treatment (Fig. 6. b). The picture Fig. b) exhibit a microstructure with fine secondary carbides without retained austenite.

The microstructures of the H11 sample are shown in Fig. 7. The micrographs on Fig. 7 represent the structure of grade $\mathrm{H} 11$ with 1000x magnification in annealed (before heat treatment) condition (Fig. 7. a), and after heat treatment (Fig. 7. b). The picture B exhibit a microstructure with tempered martensite without retained austenite.

The scanning electron micrographs of the H11 sample are shown in Fig. 8. 


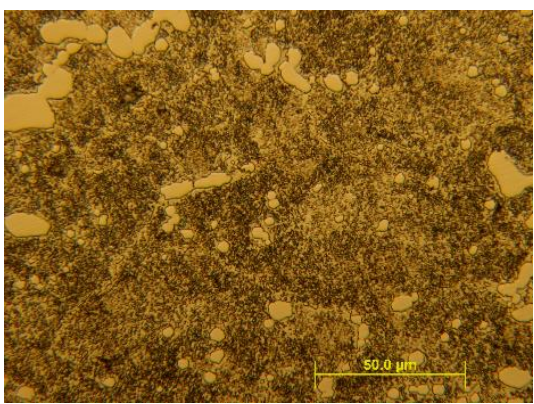

a)

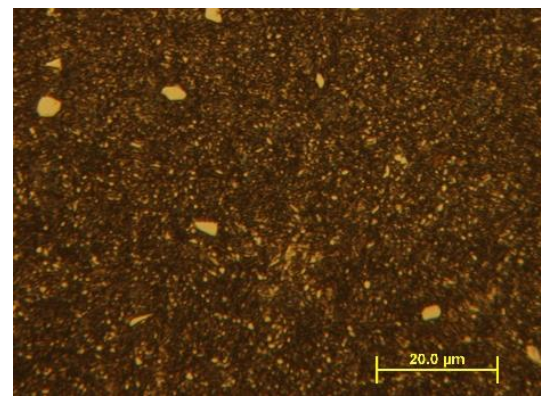

b)

Fig. 6. Microstructures of the quality grade D2: a) before heat treatment; b) after heat treatment

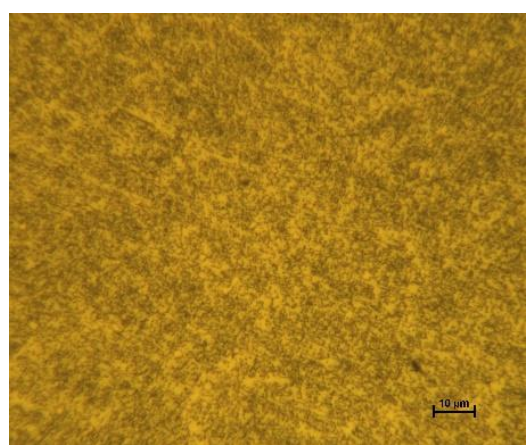

a)

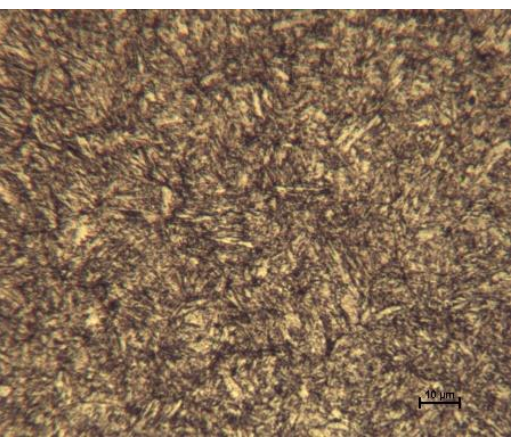

b)

Fig. 7. Microstructures of the quality grade H11: a) before heat treatment; b) after heat treatment

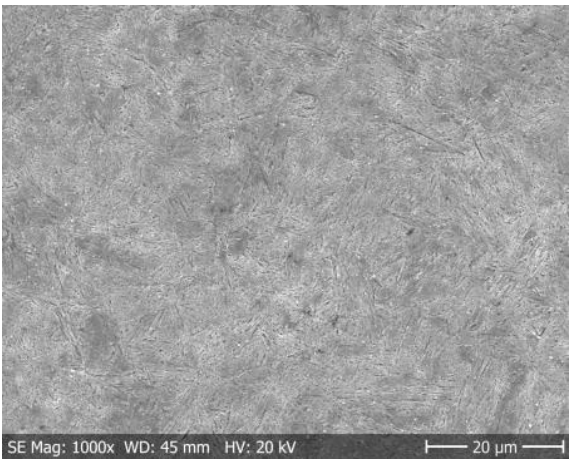

a)

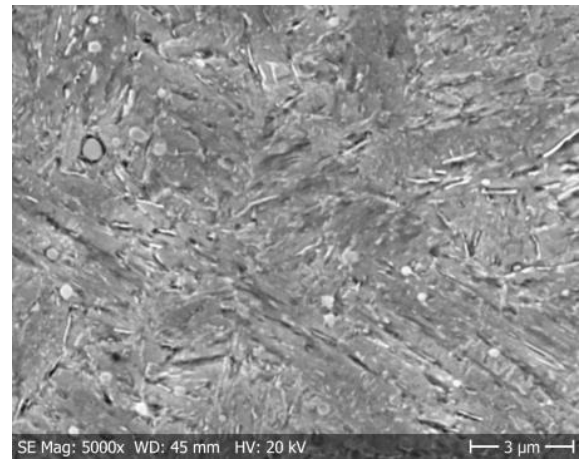

b)

Fig. 8. Scanning electron micrographs of the quality grade $\mathrm{H} 11$ at different magnifications: a) $1 \mathrm{kx}$; b) $5 \mathrm{kx}$

The picture from Fig. 8. A with 1000x magnification show a homogenous tempered martensite with $20 \mu \mathrm{m}$ average grain size. In the Fig. 8. B with 5000x magnification we could see the secondary carbides with $1 \mu \mathrm{m}$ diameter. 


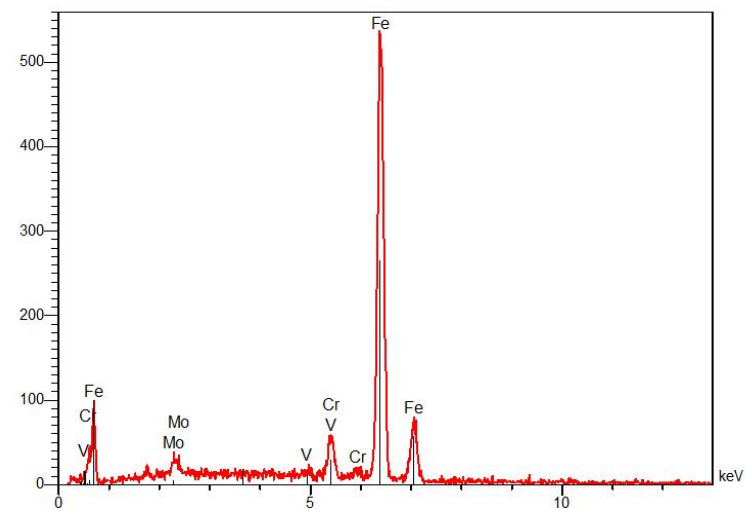

\begin{tabular}{ccccccccc}
\hline Elt & XRay & Int & Error & K & Kr & W\% & A\% & ZAF \\
\hline $\mathbf{V}$ & $\mathrm{Ka}$ & 1.0 & 0.6685 & 0.0060 & 0.0059 & 0.54 & 0.60 & 1.0899 \\
\hline $\mathbf{C r}$ & $\mathrm{Ka}$ & 8.7 & 0.6685 & 0.0602 & 0.0596 & 4.95 & 5.36 & 1.2030 \\
\hline $\mathbf{F e}$ & $\mathrm{Ka}$ & 100.6 & 0.6685 & 0.9147 & 0.9054 & 91.80 & 92.46 & 0.9863 \\
\hline Mo & $\mathrm{La}$ & 2.3 & 0.2619 & 0.0191 & 0.0189 & 2.70 & 1.59 & 0.6990 \\
\hline & & & & 1.0000 & 0.9898 & 100.00 & 100.00 & \\
\hline
\end{tabular}

Fig. 9. Scanning electron microscopical spectrum of carbides in tempered $\mathrm{H} 11$ grade

From Fig. 9 result that in the H11 grade steel in tempered condition appeared secondary $\mathrm{Fe}, \mathrm{Cr}, \mathrm{V}$, Mo complex carbides.

\section{Conclusions}

Retained austenite has a detrimental effect on the properties of the tool steels and tool life. After quenching of high-alloy steels the formation of retained austenite is inevitable. In the case of tool steels, the amount of retained austenite can be reduced using multiple tempering. Using cryogenic treatment, the amount of residual austenite of steels can be completely eliminated.

\section{Acknowledgement}

The authors acknowledge the financial support of this work by the Hungarian State and the European Union under the EFOP-3.6.1-16-2016-00010 project.

\section{References:}

[1] Verhoeven, J.D. Steel Metallurgy for the Non_metallurgist, ASM International Materials Park, OH, 2007

[2] Tóth, L. and Fábián, E.R., The Effects of Quenching and Tempering on the Hardness and Microstructure Of a Cold Work Steel, International Journal of Engineering and Management Sciences, 2019, 4(1), pp. 286-294.

[3] Saini, B.S and Kaur, R., X-Ray diffraction, Handbook of Modern Coating Technologies, Advanced Characterization Methods, 2021, pp. 85-141, doi: 10.1016/B978-0-444-632395.00003-2.

[4] Sandu, A.V., Baltatu, M.S., Nabialek, M., Savin, A. and Vizureanu, P. Characterization and Mechanical Properties of New Alloys Used for Medical Application, Materials, 2019, 12(8), art. no. 2973, doi: 10.3398/ma1282973. 
[5] Jaber, H., Kovács, T. and Tóth, L. Effects of Water/TiO2 Nano Fluid Quenching Media on Microstructure and Properties of CK35 Steel, European Journal of Materials and Engineering, 2019, 4(2), pp. 92-100.

[6] László, T., Tünde, K., Zoltán, N. and Mhatre, U. The Abrasion Behaviour of X40CrMoV5-1 Steel Under Various Surface Treatments, Acta Materialia Transilvanica, 2020, 3(1), pp. 50-54.

[7] Kovács-Koskun. T. and Bitay, E. The hardness control in the coated surface layer, Materials Science Forum, 2013, 729, pp. 415-418.

[8] G. Krauss, Steels-Processing, Structure and Performance, ed.2., ASM International Materials Park, OH, 2015

[9] Fábián, E.R., Tóth, L. and Huszák, C. Examination of Heat Treatment on the Microstructure and Wear of Tool Steels, Acta Materialia Transylvanica, 2019, 2(2), pp. 87-92.

[10] Jovicevic-Klug, P., Jenko, M., Jovicevic-Klug, M., Setina Batic, B., Kovac, J. and Podgornic, B. Effect of deep cryogenic treatment on surface chemistry and microstructure of selected high-speed steels, Applied Surface Science, 2021, 548, art. no. 149257.

[11] Kovács-Coskun T., Péter, P. and Enikő, B. A szemcseméret és a mechanikai tulajdonságok kapcsolatának vizsgálata hegesztett varratoknál, XIV. Müszaki Tudományos Ülésszak, EME, 2013, pp.125-130.

[12] Bala, P. and Krawczyk, J. Transformations during quenching and tempering of hot-worktool steel, Metal, 2009, Hradek nad Moravici, 19-21.5.2009.

[13] Enikő Réka, F., László, T. and Csenge, H. A hőkezelési paraméterek hatásvizsgálta a szerszámacélok szövetszerkezetére és kopási viselkedésére, X. Müszaki Tudományos Közlemények, 2019, pp.1-4.

[14] Talebi, S.H., Jahazi, M. and Melkonyan, H. Retained Austenite Decomposition and Carbide Precipitation during Isothermal Tempering of a Medium Carbon Low-Alloy Bainitic Steel, Materials, 2018, 11(8), art. no. 1441.

[15] Găluşcă, G., Perju, M.C., Nejneru, C., Burduhos Nergis, D.D., Lăzărescu I., Aluminum Coating Influence on Nitride Layer Performance Deposited by MO-CVD in Fluidized Bed on Austenitic Stainless Steel Substrate, IOP Conference Series: Materials Science and Engineering, 2018, 374, art. no. 012020, doi:10.1088/1757-899X/374/1/012020.

[16] Perju, M. C., Sandu, A. V., Vizureanu, P., Nejneru, C., Tugui, C. A., Burduhos-Nergis, D. D. Microstructural Analysis of Ti/W/WC Deposition by ESD Method, Acta Physica Polonica A, 2020, 138(2), pp. 214-217.

Received: April 02, 2021

Accepted: May 05, 2021 